\title{
Some remarks concerning bureaucracy and medicine
}

\author{
By Erwin H. Ackerknecht
}

Bureaucracy is in the following not understood in a pejorative, but in a descriptive sense as a very old form of social and administrative organisation, produced by certain external situations. Bureaucracy has numerous diseases, like every organism, but is not a disease. Bureaucracy is, on account of its comparative efficiency, one of the unavoidable consequences of the growth of enterprises, political and others ${ }^{1}$.

Max Weber, the great historian of bureaucracy, has shown its great age and stated as its main characteristics: centralisation, hierarchy, separation of habitat and "bureau", special qualifications and permanent employment of the bureaucrat ${ }^{2}$. Empires like the Egyptian, Roman, Chinese have been characterised as bureaucratic. As empire formation in many of the early empires (Egypt, Mesopotamia, India, China) was connected with bureaucratic regulation of water resources, K. A. Wittfogel has baptised in 1924 the formations which Montesquieu had called oriental despotisms and Karl Marx oriental or asiatic despoties, "hydraulic societies", in maintaining the notion of oriental despotism ${ }^{3}$.

How medicine was connected with the ancient Egyptian, Chinese or Inca bureaucracies is very difficult to demonstrate and such inquiries transgress the limits of this essay. Even the following remarks on the relations of bureaucracy and medicine in moderns times and the West where these relations have become important, have to be limited to a few aspects of the problem.

Our Greek and Roman predecessors knew already certain elements of medical bureaucracy. Greek cities, for instance, are known since about 500 B.C. to have hired physicians to treat the poor and fight epidemics. The Romans installed similar contract physicians since about 100 A.D. as archiatri. The engineers and architects, who constructed or administered the famous Roman aquaeducts or cloacae, and the officials controling markets, were, through their promoting public health, actually medical bureaucrats. Rome knew also the beginnings of another important medical institution: voluntary health insurance, which produces at a certain size unavoidably bureaucracy.

Medieval cities promulgated regulations for the healing profession. They also applied the central laws, like those of Frederic II of Sicily. They hired physicians, like the Greeks had done, so called medici condotti ${ }^{4}$. Doctors 
formed in cities so called colleges, a kind of medical guilds. Guilds of tradesmen instituted medical services. The hospitals, creations of the medieval church, offered medical services (besides taking care of orphans, old people, pilgrims etc.). The administration of hospitals was to a large extent in the hands of clerical bureaucrats, who were often criticised. When the hospitals were secularised during the 15th century and the clergymen replaced by citizens, complaints did not stop. See e. g. the ordinance of Blois of $1564^{5}$. Medieval city administrators faced the same problems of clean water supplies, sewage removal, paving streets or control of markets that had beset those of ancient cities. New medieval medical inventions like quarantines or isolation of lepers needed, of course, administrators.

Medical administration and an administrative control of medicine are during the middle ages mostly found not in countries, but in smaller local units like cities. With the growth of absolutism, that is the centralised modern state during the 17 th and 18 th centuries, they tend to spread. It is no accident that bureaucracy is a French word. Tocqueville ${ }^{6}$ has shown that bureaucracy is in France a product of the abolutist state. The bureaucrats, the "intendants", no longer the churchmen, were now tackling the problems of poverty. They were thus bound to run into medical problems. The Paris chief of police de la Reynie made in 1668 serious efforts to clean up Paris.

The central bureaucrats sent in case of the numerous epidemics so called epidemic physicians or surgeons to the epidemy struck region. These were paid on a per day basis. Town physicians and surgeons existed only in a minority of places. Larger hospitals had their own surgeons. An original medical technique of the absolutist state during the 18th century was the distribution of the "Royal remedy boxes" (Boittes des remèdes du roi), from Paris to the "intendants", who had them sent to clergymen in places without medical personel ${ }^{7}$. In Paris dozens of doctors and surgeons were in charge of the king's castles, buildings, courts of justice, prisons, and military establishments. The same holds good for the numerous hospitals ${ }^{8}$. I hesitate to call these practitioners "fonctionnaires", that is bureaucrats, as they certainly could and did not make a living on the sums they received for these activities.

The ideology of the 17th century statesmen was the so called mercantilism, or cameralism. As the mercantilist administrators strove to give their states large populations, they became interested in statistics - and health. It is no accident that the "father of political arithmetic" the Britisher William Petty was by profession a physician ${ }^{9}$. Besides his call for statistics in general he asked for hospital training of physicians, medical research, for a Health 
Council for London, a 1000 beds hospital for the same city, isolation hospitals during epidemics and studies in occupational mortality. With the 1662 "Observations upon the Bills of Mortality" of his friend Graunt statistics entered medicine, and for good. Petty's contemporaries Hartlib, N. Greer and John Bellers published also plans for health reforms. Political arithmetic spread into France, Prussia, Holland, Sweden etc. The immediate practical results of Petty's plans in the health field remained modest. This is probably partly due to the brakes the English revolution had put on absolutism and therewith on centralising bureaucracy. Health politics remained parochial till 1834. Centralisation developed before the 19th century in England only in naval and military medicine. It is typical that, when attempts to improve water supplies were made, the problem was laid into the hands of private companies! Percival's Manchester Board of Health of 1795 , originating at the occasion of a typhus epidemic, did not last.

The 18th century saw the humanitarian philosophy of the enlightenment which reinforced mercantilist health policies. The classic expression of this combination is Joh. Peter Frank's "System of a complete Medical Police". The first of its nine volumes appeared in 1779. George Rosen called it a "guide for enlightened despots", the bureaucratic servant of whom Frank had been all his life long in France, Germany, Italy, Austria, and Russia. Frank deals in this imposing structure with all problems of Public Health from procreation to accidents. Police, that is government bureaucracy, played an important role in tackling these problems. Franz Anton Mai in 1800 collected the most important of Frank's ideas into a law which was approved by his prince, but never applied.

In the different German states a health bureaucracy was developing slowly during the 18th century. We find now in Germany not only city-but also distric physicians. It is interesting that most of the then fashionable medical topographies are the work of these bureaucrats. One of the earliest nuclei of state health administration in Germany was the Berlin Collegium sanitatis founded through the Brandenburg Medical Statute of 1685. In 1724 such Collegia were organised in all Prussian provinces.

In France regulations remained mostly local till the revolution of 1789 , except in military medicine. Then special commissions of the revolutionary assemblies, like the commission on mendicity of the "Constituante", presided by the Duke of la Rochefoucault Liancourt, elaborated extensive laws for medical care of the poor through cantonal physicians. But they were never applied. Heirlooms of the revolution were the internationally first 
chair of hygiene in Paris, the etatisation of hospitals, and the foundation of councils of salubrity. The first in Paris in 1802, in the following years in all large French cities. A national council came into being only after 1848. A central health bureaucracy developed in the 1830ies with the general inspectors Ségur de Peyron and Mélier. Military medical bureaucrats promoted medical care in the new colonies like Algiers after 1830.

Scientifically France was leading in hygiene during these decades with Villermé, Parent-Duchâtelet, Fodéré etc. Her practical superiority was recognised even by German and British authors ${ }^{10}$.

And yet the breakthrough of Public Health and Public Health Bureaucracy came about not in France, but in England, the industrially most developed European country. And the country of Edwin Chadwick ${ }^{11}$. Edwin Chadwick had originally studied law and had turned an ardent Benthamite. 1829-32 he had even been secretary to the master. Here he met his later medical associates, the bureaucrats Dr. Southwood Smith, Dr. Farr and Dr.J.P. Kay. In 1832 he entered the Poor Law commission, that is he became a civil servant, a "bureaucrat". The Poor Law Amendment of 1834, which put some order into the over one hundred year old Poor Law System through bureaucratic centralisation (central authority, paid officers), was based on Chadwick's report of 1833. While composing a report on child labor in factories, he concentrated his interest more and more on health problems. To him they were more engineering than therapeutic problems. He developed the "sanitary idea" and became the leader of the sanitary movement.

His magnum opus is his "Report on the sanitary condition of the laboring population" of 1842 (used a great deal by F. Engels). Chadwick's ideas were the foundations of the Public Health Act of 1848. This law prescribed a central Board of Health (of which Chadwick became the secretary).

Furthermore local boards of health with one medical officer, one inspector of nuisances, one surveyor, one treasurer and a clerk. This was a decisive step which made England the worlds leader in Public Health. It produced, of course, a bureaucratic structure. When e.g. in 1856 the district health officers of London formed an association they numbered 45. Al. Redgrave, chief factory inspector in 1883, had a staff of 45 . Chadwick was "retired" in 1854, but went on fighting in the "Health of towns Association" or the "National Association of promoting social science". And his work was continued through the Public Health Acts of 1858 and $1878^{12}$.

The series of social laws originating in the 1880ies in the new German Reich and connected with the name of chancellor Bismarck are another 
turning point in the history of social medicine - and medical bureaucracy. In 1876 the "Kaiserliches Gesundheitsamt" (Imperial Health Office) was founded, where in the Prussian tradition still the juristically trained bureaucrats were most influential. The Office was first concerned primarily with statistics. The Bismarck laws were based on the insurance principle, claimed already by Daniel Defoe, the inventor of Robinson, and realised during the 19. century in the private "Friendly Societies" of England, the "Mutuelles" of France, and the "Hilfskassen" of Germany. The law of 1883 instituted obligatory health insurance for about $10 \%$ of the working population ${ }^{13}$. Today more than half of the West German population is insured. The law was first primarily intended to replace to the sick workman the wages he lost through his disease. The medical care was of minor importance. This changed progressively in favor of medical care. In another turn, during the last decades emphasis has been put on prevention and rehabilitation. The insurance companies formed by law, the so called OKK (Ortskrankenkassen) were not the only ones in the system, which did not simplify matters. The insured could also remain members of a "Hilfskasse" or "Ersatzkasse". The OKK's formed a "Zentralverband". In 1891 the first "Vertrauensarzt" (Controlphysician) was employed by an OKK. In the 1890ies the insurances begun to open reconvalescenthomes, Tb sanatoria and eventually ambulatoria. The administration of the over 4 Million insured in 1883 needed an administration. Thus to the traditional State health bureaucracies new bureaucracies were added. The beginnings were modest. The Chemnitz office e.g. had only 6 employees in 1884. But the OKK Berlin had 99 employees (for 90000 insured) in 1905, and 500 (for 500000 insured) in 1914. The administrative expenses of the OKK were $6 \%$ of the expended total in $1913,9,3 \%$ in 193214 . In 1920 there were 27000 employees in the OKK's, in $192729000^{17}$.

There developed simultaneously a third bureaucracy, that of the doctor's organisations which were founded to represent the doctors in their dealings with the state and especially the insurances. H. E. Richter became in 1872 the father of the "Ärztevereinsbund". In 1900 the more aggressive "Hartmannbund" originated. Today we have in the BRD the "Ärztekammer", the "Niedergelassene Ärztevereinigung", the "Hartmannbund", and the "Marburger Bund", representing the doctors who work in hospitals, today almost half of the practicing physicians. They all have administrations, consisting often of law graduates. The "Kassenärztliche Vereinigung Hamburg" e.g. representing in 19832339 doctors, who treated 2,2 million patients, had in that year 273 employees, as compared to 138 in $1967^{16}$. 
In 1884 the German Insurance law against accidents was passed. It was directed by the RVA (Reichsversicherungsanstalt, Imperial Insurance Office) attached to the Ministry of Interior. Its partners were the "Berufsgenossenschaften". In 1908 it had one president, 2 directors, 23 presidents of courts, 40 permanent collaborators plus the office personel. Its service of technical supervision (the first 3 factory inspectors were installed in Prussia in 1854) comprised in 1969 in the BRD 986 employees supported by 1597 employees of the "Gewerbeaufsicht" (Tradessupervision) ${ }^{17}$. Results in accident prevention, obtained by these offices were very satisfactory.

The third Bismarck law, the law for invalidity and old age was promulgated in 1889. It is administrated by the LVA ("Landesversicherungsanstalt", State Insurance Administration). The German laws obviously corresponded to a need. No less than 6 European countries adopted similar laws during the 20 years following 1883 . The Health Insurance law had a strange byproduct. As its administration was elected by its members, and as the majority of the workmen voted socialist, it created "the possibility of rise for tens of thousands of members of the working class", otherwise excluded from state offices under the Kaiser ${ }^{15}$. Numerous German socialist leaders of the period started their careers as health insurance employees.

The German state tried several times, with limited success, to bring more order into the multiplicity of insurance organisations through the "Reichsversicherungsordnung" of 1913, and the law for simplification of health administration of 1934, which created the Public Health Service ("Öffentliches Gesundheitsamt", O.G.D.) with 738 local "Gesundheitsämter" (Health Offices).

The great progress of medicine through bacteriology brought about the opening of state or communal laboratories. May I mention in connection with bacteriology that not only Pasteur and Koch, but also e. g. Villemin, Laveran, Manson, Ehrlich, Ross, and Walter Reed were bureaucrats.

New health bureaucracies arose not only through state activities, but also such volunteer organisations as the Red Cross, the Anti-Tb, Anti-Ca, AntiPolio, and other Anti-ligues.

Though bureaucracies do fight with each other, and there is also quite some infighting in bureaucracies, one should not overlook the numerous cases when bureaucracies of different origins (state, medical, technical) have been peacefully united in common work for health goals like in the German association for Public Health ${ }^{18}$.

An apt illustration of the relations between quantity and bureaucratisa- 
tion is medical education. While in France and the USA medical schools have been run for over a hundred years by full time bureaucrats, in the German language area they were till recently still administered by a "militia system" of yearly elected deans. The enormous increase of the student population and the budgets causes now here too the replacement of the "militia men" by permanent bureaucrats.

The disappearance of family and religion has brought into the health field legions of new bureaucrats inside and outside the hospitals like e. g. the social workers (one demands now one social worker for 300 hospital beds), and the numerous subprofessions of nursing (Schipperges ${ }^{19}$ enumerates more than 40) or managing, which have completely transformed the position of the physician in hospital and society.

The size and power of modern health bureaucracies of all origins are illustrated by the magnificent buildings they, Pharaos and Kings of our time, have erected everywhere! And they can always count on the benevolent understanding of parlaments, as these consist to a considerable proportion of other bureaucrats $(40 \% \text { in the BRD })^{20}$. The State health bureaucracies, originally only appendices to other ministries, have now everywhere ministries of their own.

The USA have pioneered administratively in some filds like the Childrens Bureau in 1912, or the Food- and Drug Administration in 1916. Yet compulsory health insurance came only very late to the US. F. D. Roosevelt did not succeed to get it into the Social Security Act in the 1930ies. Only more than 20 years later, that is during the presidency of J.F. Kennedy, partial solutions like medicaid and medicare did appear. Great Britain has created the National Health Service in 1946. The totally bureaucratic socialist states have produced in total bureaucratisation of health services a logical but by no means optimal solution of the difficult problem of medical care. A very large international bureaucracy has come into being with the World Health Organisation, successor of earlier attempts like the Health Organisation of the League of Nations. Here too organisational parallels in the voluntary field like the International Health Division of the Rockefeller Foundation (founded in 1913) do exist.

\section{Footnotes}

1 F. M. Marx, Einführung in die Bürokratie, Wied 1959, p. 33.

${ }^{2}$ Max Weber, Wirtschaft und Gesellschaft, Tübingen 1957.

${ }^{3}$ K. A. Wittfogel, Oriental Despotism, New York 1959. 
${ }^{4}$ V.Nutton, The city physician in classical antiquity and medieval Italy, pp.9-46 in A.W. Russell ed. The Town and State physician in Europe from the Middle Ages to the Enlightenment. Wolfenbüttler Forschungen Band 17, Herzog-August-Bibliothek, Wolfenbüttel 1981.

5 René Sand, The advance of social medicine, London 1952, p.364.

${ }^{6}$ Al. de Tocqueville, L'Ancien Régime et la révolution, Paris 1856.

7 T. Gelfand, Public medicine and medical careers in France during the reign of Louis XV, in Russell, l.c.p.99-122.

${ }^{8}$ P. Delaunay, Le monde médical Parisien au $18^{\mathrm{e}}$ siècle, Paris 1905, pp. 68-166.

${ }^{9}$ G. Rosen, History of Public Health, New York 1958, pp. 192-221, id. From Medical Police to Social Medicine, New York 1974, pp. 120-245.

10 E. H. Ackerknecht, Hygiene in France 1815-48, Bull. Hist. Med. 22: 117-155, 1948.

11 S. E. Finer, The life and times of Sir Edwin Chadwick, New York 1970.

12 G. Rosen, l.c. 1958, p. 229.

${ }^{13}$ F.Tennstedt, Sozialgeschichte der Sozialversicherung, in M.Blohmke, Handbuch der Sozialmedizin, Stuttgart 1976, pp.385-492.

E. Liek, Der Arzt und seine Sendung, München 1926, p. 28.

${ }^{14}$ F. Tennstedt, Porträts und Skizzen zur Geschichte der Sozialpolitik in Deutschland, Kassel 1984, p. 303.

15 Ed. Heimann, Soziale Theorie des Kapitalismus, Tübingen 1929, p. 199, zitiert in F. Tennstedt, Geschichte der Selbstverwaltung in der Krankenversicherung, Bonn 1977, p. 124.

16 H. Rodegra, 30 Jahre Selbstverwaltung der Hamburger Kassenärzte, Hamburg 1984.

17 Tennstedt l.c. 1976, p. 443.

18 Alf. Fischer, Geschichte des öffentlichen Gesundheitswesen, Hildesheim 1965, p. 440.

19 H.Schipperges, Medizinische Dienste im Wandel, Baden-Baden 1973, p. 32.

${ }^{20}$ Henry Jacoby, Die Bürokratisierung der Welt, Neuwied 1969. A good cross section of German Health bureaucracies in H. Kater, Politiker und Ärzte, Hameln 1968.

\section{Zusammenfassung}

Die Verbindung von Medizin und Bürokratie beginnt bereits im alten Griechenland und in Rom mit den Stadtärzten, die auch in den mittelalterlichen Städten existieren. Die von Klerikern geleiteten Spitäler, die Leprosorien und Quarantänen haben ebenfalls Bürokratien. Mit dem Wachsen des Absolutismus dehnt sich die bürokratische Kontrolle der Medizin von den Städten auf den ganzen Staat aus. Die «politische Arithmetik» (Statistik) des Dr. William Petty, «die Medezinische Polizei» des Joh. Peter Frank, die «Conseils de Salubrité» der Französischen Revolution sind weitere Etappen. Den Sieg der öffentlichen Gesundheitspflege und ihrer Bürokratie bringt der Jurist Edwin Chadwick mit seinem Gesetz von 1848. Bismarcks Gesundheitsgesetze (nach 1883) schaffen eine neue Bürokratie, die Kassenbürokratie. Die Bürokratien der Ärzteorganisationen, der freiwilligen Organisationen wie Rotkreuz, Krebsliga usw. folgen. Die Spitalbürokratie wird erweitert durch Sozialarbeiter, Pflege-, Laborpersonal usw. Neue Bürokratien entstehen in den USA und in Großbritannien, der WHO, den Staaten der Entwicklungsländer, der Rockefeller Foundation, usw.

Prof. Dr. med. Erwin H. Ackerknecht, Ottikerstraße 42, CH-8006 Zürich 